\title{
Stimulation of $\beta$-catenin and colon cancer cell growth by the KDM4B histone demethylase
}

\author{
WILLIAM L. BERRY ${ }^{1}$, TAE-DONG KIM ${ }^{1}$ and RALF JANKNECHT ${ }^{1,2}$ \\ ${ }^{1}$ Department of Cell Biology and ${ }^{2}$ Peggy and Charles Stephenson Cancer Center, \\ University of Oklahoma Health Sciences Center, Oklahoma City, OK 73104, USA
}

Received November 19, 2013; Accepted December 21, 2013

DOI: 10.3892/ijo.2014.2279

\begin{abstract}
The linchpin of colorectal cancer is the oncoprotein and transcriptional cofactor $\beta$-catenin, whose overexpression is causative for the neoplastic transformation of colon cells. However, the molecular details of $\beta$-catenin dependent gene transcription in cancer cells are still not comprehensively explored. Here, we show that the histone demethylase KDM4B was upregulated in colon and rectal adenocarcinomas and required for efficient growth and clonogenic activity of human HT-29 colon cancer cells. Moreover, KDM4B formed complexes with $\beta$-catenin in vitro and in vivo, which involved its central amino acids 353-740. In addition, KDM4B also interacted with the DNA-binding protein TCF4, which is the main factor recruiting $\beta$-catenin to chromatin in the intestine. KDM4B downregulation resulted in reduced expression of the $\beta$-catenin/TCF4 target genes JUN, MYC and Cyclin D1, all of which encode for oncoproteins. Collectively, our data indicate that KDM4B overexpression supports $\beta$-catenin mediated gene transcription and thereby contributes to the genesis of colorectal tumors. Accordingly, inhibition of the KDM4B histone demethylase may represent a novel avenue of fighting colorectal cancer, one of the major causes of cancer death throughout the world.
\end{abstract}

\section{Introduction}

Colorectal cancer is a major health issue and over 50,000 US residents alone are expected to die from this disease this year (1). A crucial defect in the vast majority of colorectal tumors is the overexpression of the oncoprotein $\beta$-catenin. This is primarily due to the loss of the tumor suppressor adenomatous polyposis coli (APC), which normally directs the intracellular destruction of $\beta$-catenin, or activating mutations in $\beta$-catenin

Correspondence to: Dr Ralf Janknecht, University of Oklahoma Health Sciences Center, 975 NE 10th Street, BRC-1464, Oklahoma City, OK 73104, USA

E-mail: ralf-janknecht@ouhsc.edu

Key words: $\beta$-catenin, colon cancer, gene transcription, histone demethylase, KDM4B itself (2). Unfortunately, knowledge on the devastating impact of these genetic mutations has not yet translated into improved therapy.

Aside from genetic mutations, epigenetic changes are an underlying cause of tumorigenesis. Most prominently, such epigenetic changes involve the methylation of DNA on cytosine residues and the modification of histones by acetylation and methylation $(3,4)$. In contrast to DNA methylation and histone acetylation, the methylation of histones was only recently validated as a major epigenetic mechanism. Methylation occurs on lysine and arginine residues at multiple sites on histones and the tight regulation of the histone methylation status is absolutely required for normal cell physiology and safeguards against aberrant cell growth. Thus, enzymes affecting histone methylation play seminal roles in cellular homeostasis and, accordingly, dysregulation of both histone methyltransferases as well as the opposing demethylases is thought to be capable of inducing cancer $(5,6)$. However, the roles of the enzymes determining histone methylation in colorectal tumors are largely unexplored.

The family of human Jumonji $C$ domain containing proteins comprises 30 members, many of which have been shown to function as histone demethylases (7). These include the four related lysine-specific demethylase 4 (KDM4) proteins, KDM4A-D (8). They can demethylate histone H3 on lysines 9 and 36 as well as histone H1.4 on lysine 26 (9-15). Notably, KDM4A, B and C are overexpressed in human breast tumors and promote proliferation of breast tumor cells, in part due to their ability to function as cofactors of estrogen receptor $\alpha$ (16-21). Likewise, all four KDM4 proteins were shown to coactivate the androgen receptor and may thereby contribute to prostate tumor formation (22-24). Despite these examples of overlapping function, KDM4 proteins can also behave differently from each other (8). For instance, KDM4B seems to be less catalytically active $(9,12)$ and is the only KDM4 protein that is robustly overexpressed under hypoxia $(25,26)$. Here, we explored the role of KDM4B in colorectal cancer.

\section{Materials and methods}

Lentivirus mediated KDM4B downregulation with shRNA. To generate an inducible miRshRNA entry vector, annealed oligonucleotides KDM4B-shRNA sense (5'-AGCGAGCG CTGACACTGTATTCTTATTAGTGAAGCCACAGATGTA 
ATAAGAATACAGTGTCAGCGC-3') and KDM4B-shRNA antisense (5'-GGCAGGCGCTGACACTGTATTCTTATT ACATCTGTGGCTTCACTAATAAGAATACAGTGTCAGC GCT-3') were cloned into pEN_TTRmiRc2 (Addgene). To transfer sequences into the lentiviral destination vector, the miRshKDM4B entry vector was incubated together with pSLIK Hygro (Addgene) and Clonase 2 (Invitrogen) per company instructions. The resulting miRshKDM4B lentiviral expression vector was cotransfected along with packaging plasmids pMD2.G (Addgene), pMDL/RRE g/p (Addgene) and pRSV-Rev (Addgene) into 293T cells. Cells were seeded at $\sim 60 \%$ confluence and DNA was delivered using the polyethylenimine transfection method overnight. Polyethylenimine to DNA ratio was 3:1. Forty-eight and $72 \mathrm{~h}$ post-transfection, supernatant was harvested and filtered through a $0.45-\mu \mathrm{m}$ membrane. Cleared viral supernatant was concentrated using poly(ethylene glycol)-8000 and used to infect HT-29 cells (27).

Cell proliferation assay. HT-29 cells that inducibly expressed shRNA targeting KDM4B were seeded into 96-wells and grown in DMEM medium plus $10 \%$ fetal calf serum. One day thereafter, the cell number was determined for the first time and defined as number of cells at day 0 . Then, cells were mock treated or with $500 \mathrm{ng} / \mathrm{ml}$ doxycycline and cell numbers measured at the indicated days thereafter with the TACS (Trevigen) MTT (3-[4,5-dimethylthiazol-2-yl]-2,5-diphenyltetrazolium bromide) kit (28). Averages with standard errors of triplicate experiments were determined.

Clonogenic assay. Cells were seeded at 5,000 cells per well. Thereafter, cells were mock treated or with $500 \mathrm{ng} / \mathrm{ml}$ doxycycline and grown in DMEM medium plus 10\% fetal calf serum. Media without and with doxycycline were replenished every four days for twelve days. The cells were then fixed in $3.7 \%$ formaldehyde for $10 \mathrm{~min}$ and stained with $1 \%$ crystal violet blue for $30 \mathrm{~min}$. After rinsing with distilled water, cells were photographed.

Coimmunoprecipitation assays. Human embryonic kidney $293 \mathrm{~T}$ cells were grown in a humidified atmosphere in $10 \% \mathrm{CO}_{2}$ at $37^{\circ} \mathrm{C}(29)$. Cells were seeded into 6 -cm dishes that were coated with poly-L-lysine 12-24 h before transfection (30). Cells were then transiently transfected by the calcium phosphate coprecipitation method (31) and lysed $36 \mathrm{~h}$ after transfection with $50 \mathrm{mM}$ Tris- $\mathrm{HCl}(\mathrm{pH} 7.4), 150 \mathrm{mM} \mathrm{NaCl}$, $50 \mathrm{mM} \mathrm{NaF}, 0.25 \mathrm{mM} \mathrm{Na} \mathrm{VO}_{4}, 0.5 \%$ Igepal CA-630, $10 \mu \mathrm{g} /$ $\mathrm{ml}$ leupeptin, $2 \mu \mathrm{g} / \mathrm{ml}$ aprotinin, $1 \mu \mathrm{g} / \mathrm{ml}$ pepstatin A, $0.5 \mathrm{mM}$ PMSF, $0.2 \mathrm{mM}$ DTT. Immunoprecipitation was performed with anti-Flag M2 or anti-Myc 9E10 monoclonal antibodies as described (32). Coprecipitated proteins were detected by western blotting employing enhanced chemiluminescence (33).

Glutathione S-transferase (GST) pull-downs. GST fusion proteins were produced in Escherichia coli and purified as previously described (34). Cell extract containing Myc-tagged $\beta$-catenin protein was prepared from transiently transfected 293T cells (35). This extract was then incubated for $3 \mathrm{~h}$ at $4^{\circ} \mathrm{C}$ with GST fusion proteins bound to glutathione agarose beads utilizing $20 \mathrm{mM}$ HEPES (pH 7.4), $50 \mathrm{mM} \mathrm{NaCl}, 1 \mathrm{mM}$ DTT,
$0.01 \%$ Tween-20, $0.5 \mathrm{mM}$ PMSF as a binding buffer. After three washes in the same buffer, any bound Myc-tagged $\beta$-catenin was revealed by western blotting employing anti-Myc 9E10 monoclonal antibodies.

Reporter gene assay. HT-29 cells inducibly expressing KDM4B shRNA were infected with pBARLS lentivirus (kind gift from Dr Randall Moon) that encodes 12 TCF4 binding elements upstream of luciferase cDNA. Equal numbers of cells were then split into two groups of triplicates and treated without and with $500 \mathrm{ng} / \mathrm{ml}$ doxycycline for $72 \mathrm{~h}$. Then, cells were lysed as described before (36) and luciferase activities derived from pBARLS were measured in a Berthold LB9507 luminometer (37).

Reverse transcription-polymerase chain reaction (RT-PCR). RNA was isolated employing TRIzol (Invitrogen) and utilized in the Access RT-PCR kit (Promega) as described before (38). Oligonucleotides used were 5'-GTGACCGCGACTTTTCA AAGC-3' and 5'-CGTTGCTGGACTG GATTATCAG-3' for JUN, 5'-TGAGGAGACACCGCCCAC-3' and 5'-CAACATCG ATTTCTTCCTCATCTTC-3' for MYC, 5'-AAGGCGGAGG AGACCTGCGCG-3' and 5'-ATCGTGCGGGGTCATTGC GGC-3' for Cyclin D1, and 5'-GAGCCACATCGCTCAGAC ACC-3' and 5'-TGACAAGCTTCCGCTTCTCAGC-3' for GAPDH. Resulting PCR products were separated on agarose gels and stained with ethidium bromide (39).

Chromatin immunoprecipitations. These were performed essentially as described before (40) with rabbit KDM4B antibodies either from Bethyl (A301-478A) in case of the JUN promoter or from Novus Biologicals (NBP1-67802) in case of the Cyclin D1 promoter. For promoter fragment amplification, nested PCR was employed using the temperature program $98^{\circ} \mathrm{C}$ for $2 \mathrm{~min} ; 8$ cycles of $98^{\circ} \mathrm{C}$ for $30 \mathrm{sec}, 65^{\circ} \mathrm{C}\left(-1^{\circ} \mathrm{C}\right.$ per cycle) for $30 \mathrm{sec}, 72^{\circ} \mathrm{C}$ for $25 \mathrm{sec}$; 18 cycles (in the first PCR) or 15 cycles (in the second PCR) of $98^{\circ} \mathrm{C}$ for $30 \mathrm{sec}, 57^{\circ} \mathrm{C}$ for $30 \mathrm{sec}, 72^{\circ} \mathrm{C}$ for $25 \mathrm{sec}(+1 \mathrm{sec}$ per cycle), followed by a final 4-min extension at $72^{\circ} \mathrm{C}(41)$. The iProof high fidelity DNA polymerase (Bio-Rad) was used in the first PCR and GoTaq polymerase with 5X Green buffer (Promega) in the second PCR. The primers for the first PCR were: Jun-ChIP-2805-for (5'-GGCAGCCACCGTCACTAGACAGTC-3') and Jun-ChIP3184-rev (5'-GCCACACTCAGTGCAACTCTGAGC-3'), or D1-pro-for6 (5'-GTAACGTCACACGGACTACAGG-3') and D1-pro-rev5 (5'-GCACACATTTGAAGTAGGACACC-3'). The primers for the second PCR were: Jun-ChIP-2834-for (5'-CCAAGACGTCAGCCCACAATGCACC-3') and Jun-ChIP-3145-rev (5'-GCTCAACACTTATCTGCTACCA GTC-3'), or D1-ChIP-2726-for (5'-GTTGCAAAGTCCTGGA GCCTCCAG-3') and D1-ChIP-2982-rev (5'-CGGTCGTTGAG GAGGTTGGCATCG-3'). The resultant 312 bp JUN promoter and 257 bp Cyclin D1 promoter fragments were revealed by agarose gel electrophoresis (42).

\section{Results}

Overexpression of KDM4B in colorectal tumors. To comprehensively assess the expression pattern of KDM4 genes in human colorectal tumors, we performed in silico 

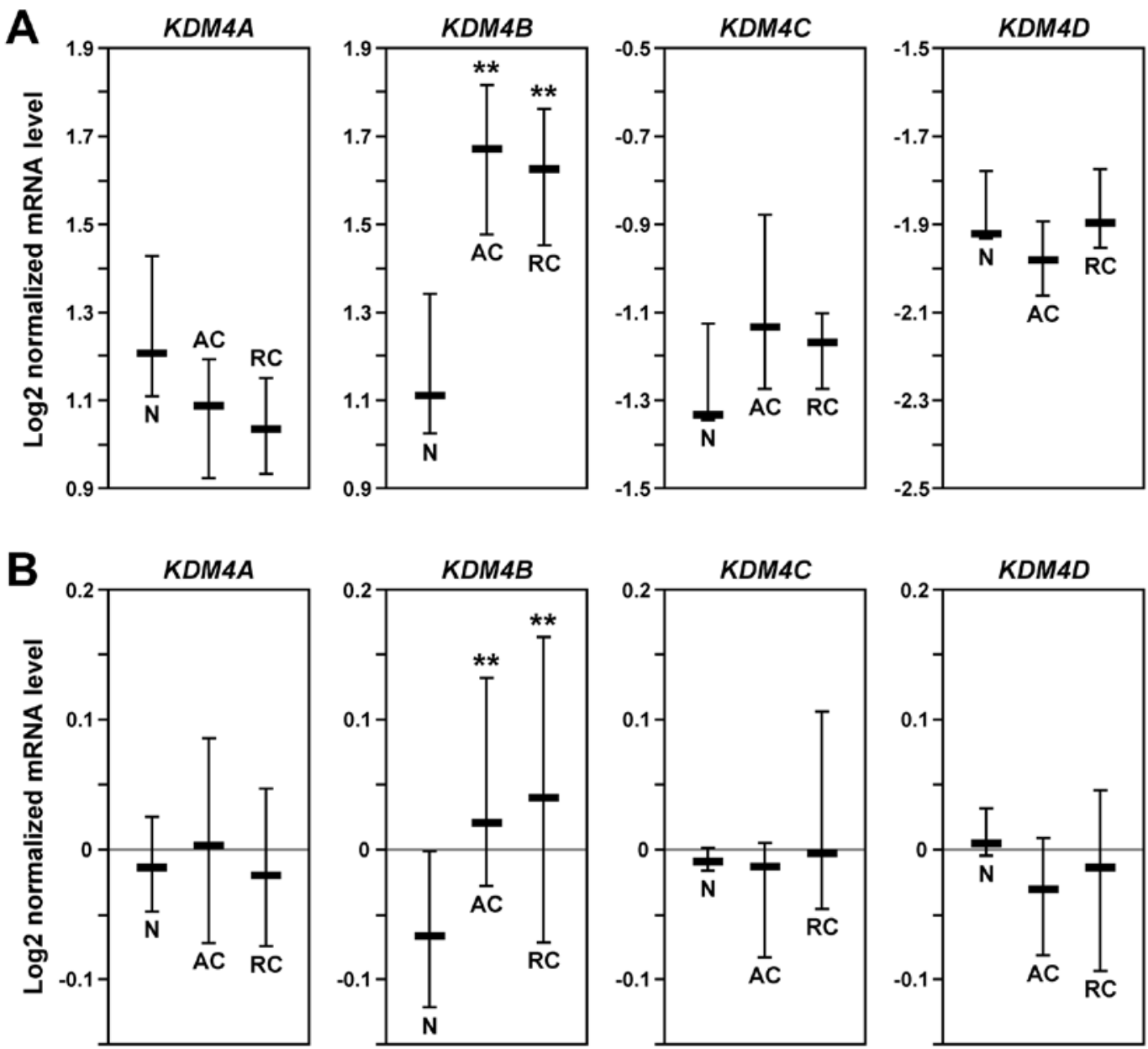

Figure 1. KDM4 mRNA levels in human colorectal cancer. Shown are medians with $25-75$ percentile intervals of $\log 2$ transformed mRNA datasets. ${ }^{* * *}$ p $<0.002$ (Student's t-test). (A) Microarray data set from Kaiser et al (43). Five normal (N), 41 colon adenocarcinomas (AC) and 8 rectal adenocarcinomas (RC) were compared. (B) Microarray data set from Kurashina et al (44). Ninety-four normal, 52 colon and 38 rectal adenocarcinomas were included.

analyses comparing normal and cancer tissues with the help of Oncomine (www.oncomine.org). In two independent data sets $(43,44)$, KDM4B mRNA was significantly upregulated in both colon and rectal adenocarcinomas compared to normal colon tissue, whereas no relevant upregulation of KDM4A, KDM4C or KDM4D was observable (Fig. 1). These data implicate that elevated KDM4B levels, but not overexpression of any of the other three KDM4 family members, play a role in the development of colorectal tumors.

Growth deficit of colon cancer cells following loss of KDM4B. To test the impact of KDM4B on cell physiology, we infected human HT-29 colon cancer cells with lentivirus that doxycycline-inducibly expressed KDM4B shRNA. After selection for viral integration, these cells were treated with and without doxycycline, which resulted in efficient downregulation of KDM4B (Fig. 2A). Importantly, doxycycline treatment significantly reduced HT-29 cell growth (Fig. 2A), suggesting that KDM4B has a pro-growth effect. We also determined the importance of KDM4B for growing colonies from single cells, another litmus test for oncogenic activity. When treated with doxycycline to ablate KDM4B expression, HT-29 cells displayed a markedly reduced ability to establish colonies
(Fig. 2B). Altogether, these results support the notion that KDM4B promotes neoplastic growth of colon cells.

Complex formation of KDM4B with $\beta$-catenin. Overexpression of the $\beta$-catenin oncoprotein, the linchpin of colon tumorigenesis, is observed in $>80 \%$ of sporadic colorectal tumors (2). Like KDM4B, $\beta$-catenin is a transcriptional cofactor (45). Therefore, we tested whether KDM4B might interact with $\beta$-catenin. To this end, we coexpressed Flag-tagged $\beta$-catenin with Myc-tagged KDM4B in 293T cells and performed coimmunoprecipitation experiments. We found that $\beta$-catenin coprecipitated with KDM4B (Fig. 3A). Similarly, in a reverse order coimmunoprecipitation experiment, KDM4B coprecipitated with $\beta$-catenin (Fig. 3B). These data demonstrate that KDM4B and $\beta$-catenin form complexes in vivo.

Next, we explored whether $\beta$-catenin would bind to KDM4B in vitro and which domains of KDM4B would be involved. To this end, we divided KDM4B into three parts and purified respective GST fusion proteins. These were then bound to glutathione agarose beads, which were subsequently incubated with a cell extract containing Myc-tagged $\beta$-catenin. No binding of $\beta$-catenin to the GST moiety itself was detectable, but it interacted with KDM4B amino acids 353-740 (Fig. 4A). 

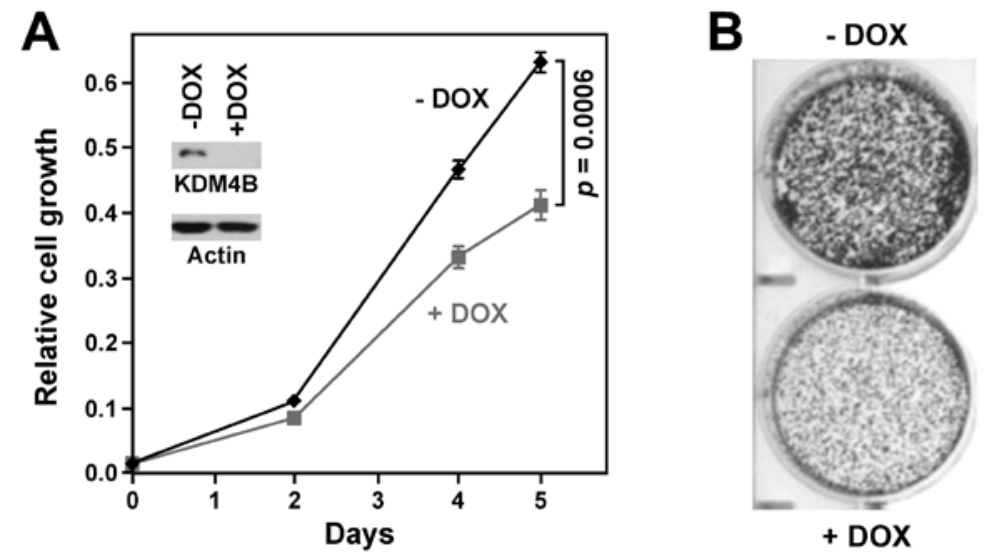

Figure 2. Impact of KDM4B on HT-29 colon cancer cells that were engineered to express KDM4B shRNA in a doxycycline-inducible manner. (A) Analysis of cell growth after challenge with doxycycline (DOX) or mock treatment. Statistical significance was determined with an unpaired, two-tailed t-test. The inset shows corresponding western blots for KDM4B and actin as a loading control. (B) Representative clonogenicity assay. Cells were treated without and with DOX for two weeks and then stained with crystal violet.

A

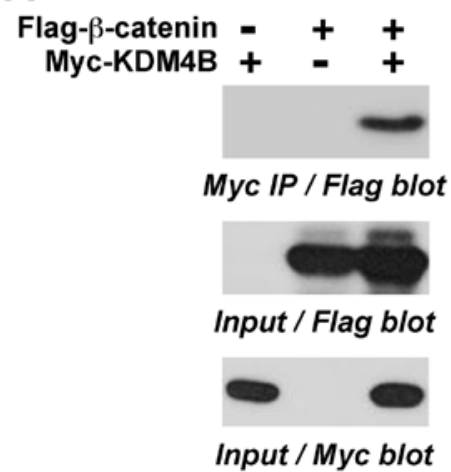

B

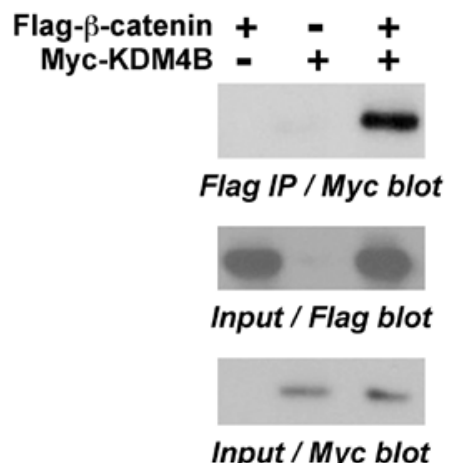

Input / Myc blot

Figure 3. Interaction of KDM4B with $\beta$-catenin. (A) Flag-tagged $\beta$-catenin was coexpressed with Myc-tagged KDM4B in 293T cells. After anti-Myc immunoprecipitation (IP), coprecipitated $\beta$-catenin was detected by anti-Flag western blotting (top panel). The bottom panels reveal input levels of Flag- $\beta$-catenin and Myc-KDM4B. (B) Reverse order coimmunoprecipitation assay.

These amino acids are devoid of any known structural motifs (Fig. 4B). In contrast, $\beta$-catenin did not appreciably bind to the N-terminal KDM4B amino acids 2-352 encompassing the catalytic JmjC and JmjN domains or the C-terminal amino acids 741-1130, which contain the double PHD and TUDOR domains that are involved in recognizing methylated histone residues $(8,46)$. Collectively, our data reveal that KDM4B and $\beta$-catenin interact both in vitro and in vivo.

Coactivation of gene transcription by KDM4B. The $\beta$-catenin protein itself does not directly bind to DNA. Rather, it is primarily recruited to chromatin in the intestine by the DNA-binding transcription factor TCF4 (47). Therefore, we reasoned that not only $\beta$-catenin, but also TCF4 might form a complex with KDM4B. To test this hypothesis, we coexpressed Flag-tagged KDM4B and Myc-tagged TCF4 in 293T cells, immunoprecipitated with Flag antibodies and then tested for coprecipitated TCF4 by anti-Myc western blotting. Indeed, TCF4 coprecipitated with KDM4B (Fig. 5A), implicating that a tripartite complex of TCF4, $\beta$-catenin and KDM4B can be formed.

To determine whether KDM4B stimulates or represses $\beta$-catenin/TCF4-dependent transcription, we employed a
A

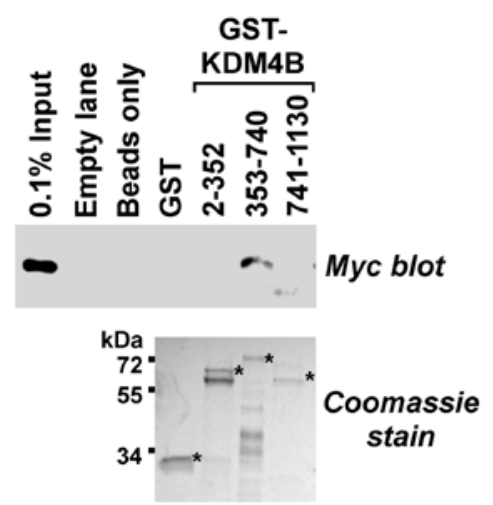

B

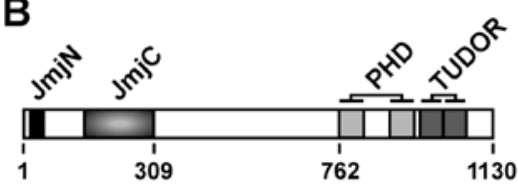

Figure 4. (A) GST pull-down assays. Binding of Myc-tagged $\beta$-catenin to indicated KDM4B amino acids fused to GST or the GST moiety alone was assessed (top panel). The bottom panel shows that comparable levels of GST fusion proteins were employed. (B) Sketch of human KDM4B (1130 amino acids long isoform). 

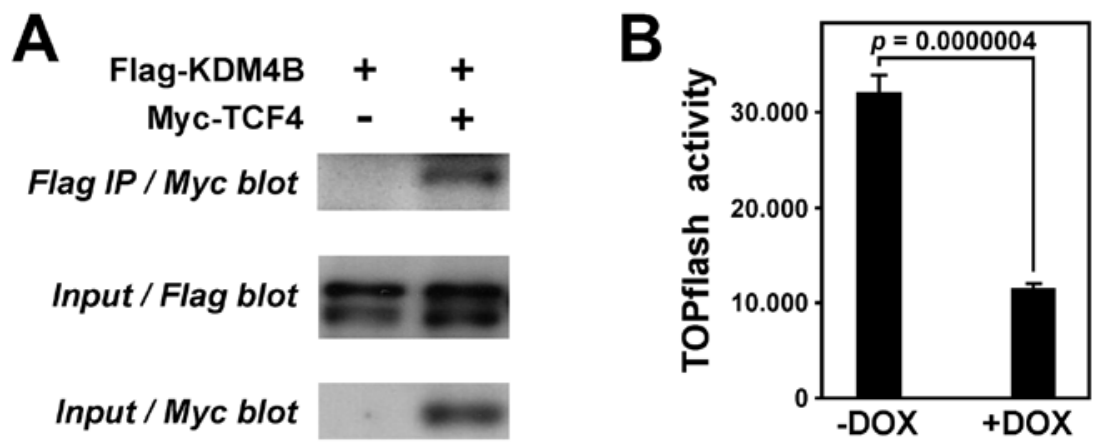

Figure 5. (A) Coimmunoprecipitation of Myc-tagged TCF4 with Flag-tagged KDM4B in 293T cells. (B) HT-29 cells expressing doxycycline-inducible KDM4B shRNA were infected with a lentiviral TOPflash vector. Resulting TOPflash luciferase activities were measured in the absence and presence of doxycycline.
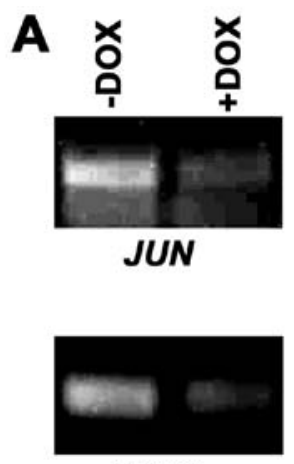

MYC

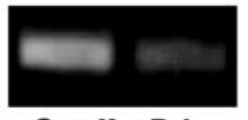

Cyclin D1

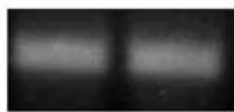

GAPDH
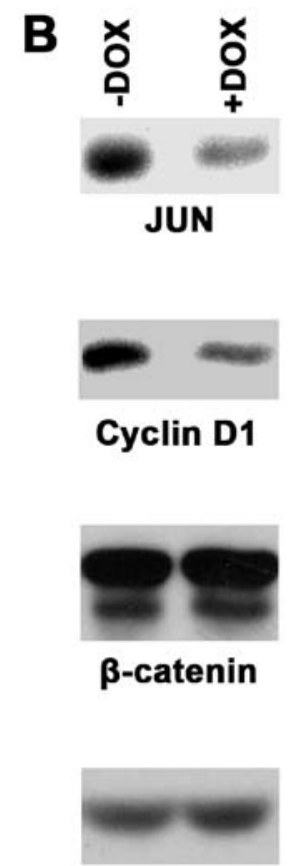

Actin
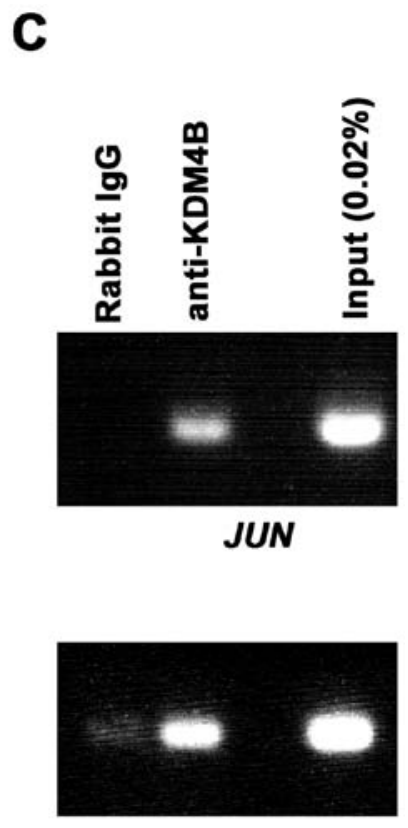

Cyclin D1

Figure 6. Impact of KDM4B on $\beta$-catenin/TCF4 target genes. (A) RT-PCR analysis of HT-29 cells treated without or with doxycycline to downregulate KDM4B. This RNA was isolated from the same cells as used in Fig. 2A. (B) Corresponding western blots. (C) Chromatin immunoprecipitation experiments in HT-29 cells. Shown are PCR amplified JUN and Cyclin D1 promoter fragments.

TOPflash luciferase reporter system that specifically measures $\beta$-catenin/TCF4-dependent transcription in colon cells (48). A lentiviral vector was employed to stably introduce the luciferase reporter gene into our HT-29 colon cancer cells that doxycycline-inducibly expressed KDM4B shRNA. In the absence of doxycycline, high luciferase activity was expectedly observable (Fig. 5B). However, upon depletion of KDM4B after doxycyline treatment, luciferase activity was $\sim 3$-fold reduced, indicating that $\mathrm{KDM} 4 \mathrm{~B}$ can stimulate $\beta$-catenin/ TCF4-dependent gene transcription.

We next sought to assess how endogenous target genes of $\beta$-catenin/TCF4 would be affected by KDM4B downregulation. Specifically, we studied three oncogenes encoding the JUN or MYC transcription factor or the cell cycle regulator Cyclin D1, all of which are bona fide targets of $\beta$-catenin/ TCF4 (48-51). When utilizing our doxycycline-inducible
KDM4B shRNA expressing HT-29 cells, we observed that JUN, MYC and Cyclin D1 transcription became reduced upon KDM4B downregulation, whereas the control GAPDH was unaffected (Fig. 6A). In addition, western blotting showed that this also held true at the protein level for JUN and Cyclin D1 (Fig. 6B), whereas MYC protein expression was below our detection level (not shown); as controls, neither $\beta$-catenin nor actin protein levels were affected by KDM4B downregulation (Fig. 6B).

Finally, we assessed whether KDM4B would bind to the JUN or Cyclin D1 gene promoter. To this end, we performed chromatin immunoprecipitation experiments. While control IgG antibodies barely or not at all led to precipitation of promoter fragments, KDM4B antibodies were able to robustly precipitate both JUN and Cyclin D1 promoter fragments (Fig. 6C). This indicates that JUN and Cyclin D1 are directly 
regulated by KDM4B. Altogether, our data provide evidence that KDM4B coactivates $\beta$-catenin/TCF4-dependent gene transcription.

\section{Discussion}

The data described in this report provide novel information. First, we discovered that the KDM4B histone demethylase is appreciably upregulated at the mRNA level in colorectal tumors, whereas none of the other three KDM4 family members is. Second, we showed that growth and colony formation ability of HT-29 colon cancer cells is stimulated by KDM4B, and third, we revealed that KDM4B is capable of forming complexes with $\beta$-catenin and TCF4 and can thereby enhance transcription of oncogenes such as JUN, MYC and Cyclin D1. Altogether, these data strongly suggest that KDM4B has oncogenic properties in colorectal cells.

KDM4B is a histone demethylase that especially demethylates trimethylated H3K9, H3K36 and H1.4K26 $(9,12,14)$. In general, both trimethylated $\mathrm{H} 3 \mathrm{~K} 9$ and $\mathrm{H} 1.4 \mathrm{~K} 26$ at a gene promoter are associated with a transcriptionally repressed status of chromatin $(52,53)$, providing an explanation how KDM4B may stimulate gene transcription by removing these repressive marks. On the other hand, trimethylated H3K36 has a variety of functions: it may promote transcription elongation but suppress transcription initiation at the promoter (54). Thus, the net effect on gene expression upon removal of H3K36 trimethylation by KDM4B is debatable. However, since KDM4 proteins appear to more efficiently target H3K9 than H3K36 (8), it is likely that the effect of KDM4B on gene transcription is primarily governed by its ability to demethylate trimethylated H3K9 (and H1.4K26) and accordingly KDM4B overexpression should result in enhanced transcription of target genes like JUN, MYC and Cyclin D1.

MYC and JUN encode for DNA-binding transcription factors and are prominent oncogenes $(55,56)$. They are also $\beta$-catenin target genes $(48,49)$ and upregulated in human colorectal tumors $(57,58)$. Interestingly, JUN can form complexes with $\beta$-catenin and TCF4, which stabilizes the $\beta$-catenin/TCF4 complex and enhances $\beta$-catenin dependent transcription $(59,60)$. Furthermore, a dominant-negative version of JUN was able to suppress the tumorigenic potential of HT-29 colon cancer cells and JUN inactivation also reduced gastrointestinal tumor formation in the $\mathrm{APC}^{\mathrm{Min}}$ mouse model, in which inactivation of APC leads to $\beta$-catenin overexpression $(59,61)$. Likewise, the cell cycle regulator Cyclin D1 is upregulated in colorectal tumors (62) and its ablation suppressed tumor formation in $\mathrm{APC}^{\mathrm{Min}}$ mice (63). Thus, stimulation of JUN, MYC and Cyclin D1 expression by KDM4B is predicted to promote colorectal tumor formation.

Cooperation with $\beta$-catenin may not be the only mechanism by which KDM4B contributes to the causation of colorectal cancer. Recently, it was reported that KDM4B is involved in the stimulation of hypoxia-inducible genes in colon cancer (64). Possibly, this may involve complex formation of KDM4B with the hypoxia-inducible factor $1 \alpha$, the master mediator of the hypoxic response, since a relative of KDM4B, the KDM4C protein, can actually bind to hypoxia-inducible factor $1 \alpha(65)$. Moreover, KDM4A is capable of binding to the p53 tumor suppressor in colon cancer cells and inhibit p53-dependent transcription (66), raising the possibility that also KDM4B might do so.

Apart from transcription regulation, KDM4B is also involved in DNA repair. Its TUDOR domains can bind to dimethylated H4K20, which normally recruits 53BP1 to sites of DNA damage and thereby facilitates repair. Notably, this activity of KDM4B is independent of its enzymatic activity (67). Accordingly, KDM4B overexpression could impair DNA repair by preventing the recruitment of 53BP1 and thereby induce genomic instability, another mechanism by which KDM4B could contribute to tumor formation. However, a recent report posits that KDM4B enhances DNA repair in a manner dependent on its enzymatic activity and thus promotes cell survival (68). This may be relevant during therapy, when KDM4B overexpression could help cancer cells to repair the DNA damage caused by radiotherapy and many chemotherapeutic agents.

In conclusion, our study highlighted the pro-growth function of KDM4B in colorectal tumors and provided a mechanism by which KDM4B may attain this through interaction with $\beta$-catenin/TCF4. Given that $\beta$-catenin is involved in many other types of cancer $(2,45)$, including breast and bladder cancer where KDM4B is also overexpressed $(18,69,70)$, the oncogenic functions of KDM4B may be of widespread importance. Thus, inhibition of KDM4B enzymatic activity or preventing its interaction with $\beta$-catenin by small molecule drugs, similar to the inhibition of chromatin recruitment of the BRD4 epigenetic regulator in acute myeloid leukemia $(71,72)$, may hold promise in cancer therapy.

\section{References}

1. Siegel R, Naishadham D and Jemal A: Cancer statistics, 2013. CA Cancer J Clin 63: 11-30, 2013.

2. Clevers $\mathrm{H}$ : Wnt/beta-catenin signaling in development and disease. Cell 127: 469-480, 2006.

3. Chi P, Allis CD and Wang GG: Covalent histone modifications-miswritten, misinterpreted and mis-erased in human cancers. Nat Rev Cancer 10: 457-469, 2010.

4. Kulis $M$ and Esteller M: DNA methylation and cancer. Adv Genet 70: 27-56, 2010.

5. Dawson MA and Kouzarides T: Cancer epigenetics: from mechanism to therapy. Cell 150: 12-27, 2012.

6. Black JC, Van Rechem C and Whetstine JR: Histone lysine methylation dynamics: establishment, regulation, and biological impact. Mol Cell 48: 491-507, 2012.

7. Kooistra SM and Helin K: Molecular mechanisms and potential functions of histone demethylases. Nat Rev Mol Cell Biol 13: 297-311, 2012.

8. Berry WL and Janknecht R: KDM4/JMJD2 histone demethylases: epigenetic regulators in cancer cells. Cancer Res 73: 2936-2942, 2013.

9. Whetstine JR, Nottke A, Lan F, Huarte M, Smolikov S, Chen Z, Spooner E, Li E, Zhang G, Colaiacovo M and Shi Y: Reversal of histone lysine trimethylation by the JMJD2 family of histone demethylases. Cell 125: 467-481, 2006.

10. Cloos PA, Christensen J, Agger K, Maiolica A, Rappsilber J, Antal T, Hansen KH and Helin K: The putative oncogene GASC1 demethylates tri- and dimethylated lysine 9 on histone H3. Nature 442: 307-311, 2006.

11. Klose RJ, Yamane K, Bae Y, Zhang D, Erdjument-Bromage H, Tempst $\mathrm{P}$, Wong $\mathrm{J}$ and Zhang $\mathrm{Y}$ : The transcriptional repressor JHDM3A demethylates trimethyl histone H3 lysine 9 and lysine 36. Nature 442: 312-316, 2006.

12. Fodor BD, Kubicek S, Yonezawa M, O'Sullivan RJ, Sengupta R, Perez-Burgos L, Opravil S, Mechtler K, Schotta G and Jenuwein T: Jmjd2b antagonizes H3K9 trimethylation at pericentric heterochromatin in mammalian cells. Genes Dev 20: 1557-1562, 2006. 
13. Shin S and Janknecht R: Diversity within the JMJD2 histone demethylase family. Biochem Biophys Res Commun 353: 973-977, 2007

14. Trojer P, Zhang J, Yonezawa M, Schmidt A, Zheng H, Jenuwein T and Reinberg D: Dynamic histone H1 isotype 4 methylation and demethylation by histone lysine methyltransferase G9a/KMT1C and the Jumonji domain-containing JMJD2/KDM4 proteins. J Biol Chem 284: 8395-8405, 2009.

15. Weiss T, Hergeth S, Zeissler U, Izzo A, Tropberger P, Zee BM, Dundr M, Garcia BA, Daujat S and Schneider R: Histone H1 variant-specific lysine methylation by G9a/KMT1C and Glp1/ KMT1D. Epigenetics Chromatin 3: 7, 2010.

16. Liu G, Bollig-Fischer A, Kreike B, van de Vijver MJ, Abrams J, Ethier SP and Yang ZQ: Genomic amplification and oncogenic properties of the GASC1 histone demethylase gene in breast cancer. Oncogene 28: 4491-4500, 2009.

17. Yang J, Jubb AM, Pike L, Buffa FM, Turley H, Baban D, Leek R, Gatter KC, Ragoussis J and Harris AL: The histone demethylase JMJD2B is regulated by estrogen receptor alpha and hypoxia, and is a key mediator of estrogen induced growth. Cancer Res 70 : 6456-6466, 2010.

18. Kawazu M, Saso K, Tong KI, McQuire T, Goto K, Son DO, Wakeham A, Miyagishi M, Mak TW and Okada H: Histone demethylase JMJD2B functions as a co-factor of estrogen receptor in breast cancer proliferation and mammary gland development. PLoS One 6: e17830, 2011.

19. Shi L, Sun L, Li Q, Liang J, Yu W, Yi X, Yang X, Li Y, Han X, Zhang Y, Xuan C, Yao Z and Shang Y: Histone demethylase JMJD2B coordinates $\mathrm{H} 3 \mathrm{~K} 4 / \mathrm{H} 3 \mathrm{~K} 9$ methylation and promotes hormonally responsive breast carcinogenesis. Proc Natl Acad Sci USA 108: 7541-7546, 2011.

20. Berry WL, Shin S, Lightfoot SA and Janknecht R: Oncogenic features of the JMJD2A histone demethylase in breast cancer. Int J Oncol 41: 1701-1706, 2012.

21. Gaughan L, Stockley J, Coffey K, O'Neill D, Jones DL, Wade M, Wright J, Moore M, Tse S, Rogerson L and Robson CN: KDM4B is a master regulator of the estrogen receptor signalling cascade. Nucleic Acids Res 41: 6892-6904, 2013.

22. Wissmann M, Yin N, Muller JM, Greschik H, Fodor BD Jenuwein T, Vogler C, Schneider R, Gunther T, Buettner R, Metzger E and Schule R: Cooperative demethylation by JMJD2C and LSD1 promotes androgen receptor-dependent gene expression. Nat Cell Biol 9: 347-353, 2007.

23. Shin S and Janknecht R: Activation of androgen receptor by histone demethylases JMJD2A and JMJD2D. Biochem Biophys Res Commun 359: 742-746, 2007.

24. Coffey K, Rogerson L, Ryan-Munden C, Alkharaif D, Stockley J, Heer R, Sahadevan K, O'Neill D, Jones D, Darby S, Staller P, Mantilla A, Gaughan L and Robson CN: The lysine demethylase, $\mathrm{KDM} 4 \mathrm{~B}$, is a key molecule in androgen receptor signalling and turnover. Nucleic Acids Res 41: 4433-4446, 2013.

25. Pollard PJ, Loenarz C, Mole DR, McDonough MA, Gleadle JM, Schofield CJ and Ratcliffe PJ: Regulation of Jumonji-domaincontaining histone demethylases by hypoxia-inducible factor (HIF)-1alpha. Biochem J 416: 387-394, 2008

26. Beyer S, Kristensen MM, Jensen KS, Johansen JV and Staller P: The histone demethylases JMJD1A and JMJD2B are transcriptional targets of hypoxia-inducible factor HIF. J Biol Chem 283 36542-36552, 2008

27. Kim TD, Oh S, Shin S and Janknecht R: Regulation of tumor suppressor p53 and HCT116 cell physiology by histone demethylase JMJD2D/KDM4D. PLoS One 7: e34618, 2012.

28. Oh S, Shin S, Lightfoot SA and Janknecht R: 14-3-3 proteins modulate the ETS transcription factor ETV1 in prostate cancer. Cancer Res 73: 5110-5119, 2013

29. Mooney SM, Grande JP, Salisbury JL and Janknecht R: Sumoylation of p68 and p72 RNA helicases affects protein stability and transactivation potential. Biochemistry 49: 1-10, 2010.

30. Janknecht R: Regulation of the ER81 transcription factor and its coactivators by mitogen- and stress-activated protein kinase 1 (MSK1). Oncogene 22: 746-755, 2003.

31. Dowdy SC, Mariani A and Janknecht R: HER2/Neu- and TAK1mediated up-regulation of the transforming growth factor beta inhibitor Smad7 via the ETS protein ER81. J Biol Chem 278: 44377-44384, 2003

32. Goel A and Janknecht R: Concerted activation of ETS protein ER81 by p160 coactivators, the acetyltransferase p300 and the receptor tyrosine kinase HER2/Neu. J Biol Chem 279: 14909-14916, 2004
33. Papoutsopoulou S and Janknecht R: Phosphorylation of ETS transcription factor ER81 in a complex with its coactivators CREB-binding protein and p300. Mol Cell Biol 20: 7300-7310, 2000.

34. Knebel J, De Haro L and Janknecht R: Repression of transcription by TSGA/Jmjd1a, a novel interaction partner of the ETS protein ER71. J Cell Biochem 99: 319-329, 2006.

35. Wu J and Janknecht R: Regulation of the ETS transcription factor ER81 by the $90-\mathrm{kDa}$ ribosomal S6 kinase 1 and protein kinase A. J Biol Chem 277: 42669-42679, 2002.

36. Rossow KL and Janknecht R: The Ewing's sarcoma gene product functions as a transcriptional activator. Cancer Res 61: 2690-2695, 2001

37. Mooney SM, Goel A, D'Assoro AB, Salisbury JL and Janknecht R: Pleiotropic effects of p300-mediated acetylation on p68 and p72 RNA helicase. J Biol Chem 285: 30443-30452, 2010.

38. Goel A and Janknecht R: Acetylation-mediated transcriptional activation of the ETS protein ER81 by p300, P/CAF, and HER2/ Neu. Mol Cell Biol 23: 6243-6254, 2003.

39. Oh S and Janknecht R: Histone demethylase JMJD5 is essential for embryonic development. Biochem Biophys Res Commun 420: 61-65, 2012.

40. Shin S, Oh S, An S and Janknecht R: ETS variant 1 regulates matrix metalloproteinase-7 transcription in $\mathrm{LNCaP}$ prostate cancer cells. Oncol Rep 29: 306-314, 2013.

41. DiTacchio L, Bowles J, Shin S, Lim DS, Koopman P and Janknecht R: Transcription factors ER71/ETV2 and SOX9 participate in a positive feedback loop in fetal and adult mouse testis. J Biol Chem 287: 23657-23666, 2012.

42. Shin S, Kim TD, Jin F, van Deursen JM, Dehm SM, Tindall DJ, Grande JP, Munz JM, Vasmatzis G and Janknecht R: Induction of prostatic intraepithelial neoplasia and modulation of androgen receptor by ETS variant 1/ETS-related protein 81. Cancer Res 69: 8102-8110, 2009.

43. Kaiser S, Park YK, Franklin JL, Halberg RB, Yu M, Jessen WJ, Freudenberg J, Chen X, Haigis K, Jegga AG, Kong S, Sakthivel B, $\mathrm{Xu} \mathrm{H}$, Reichling T, Azhar M, Boivin GP, Roberts RB, Bissahoyo AC, Gonzales F, Bloom GC, Eschrich S, Carter SL, Aronow JE, Kleimeyer J, Kleimeyer M, Ramaswamy V, Settle SH, Boone B, Levy S, Graff JM, Doetschman T, Groden J, Dove WF, Threadgill DW, Yeatman TJ, Coffey RJ Jr and Aronow BJ: Transcriptional recapitulation and subversion of embryonic colon development by mouse colon tumor models and human colon cancer. Genome Biol 8: R131, 2007.

44. Kurashina K, Yamashita Y, Ueno T, Koinuma K, Ohashi J, Horie H, Miyakura Y, Hamada T, Haruta H, Hatanaka H, Soda M, Choi YL, Takada S, Yasuda Y, Nagai H and Mano H: Chromosome copy number analysis in screening for prognosisrelated genomic regions in colorectal carcinoma. Cancer Sci 99: $1835-1840,2008$

45. Clevers $\mathrm{H}$ and Nusse $\mathrm{R}$ : Wnt/beta-catenin signaling and disease. Cell 149: 1192-1205, 2012.

46. Yap KL and Zhou MM: Keeping it in the family: diverse histone recognition by conserved structural folds. Crit Rev Biochem Mol Biol 45: 488-505, 2010.

47. Mosimann C, Hausmann G and Basler K: Beta-catenin hits chromatin: regulation of Wnt target gene activation. Nat Rev Mol Cell Biol 10: 276-286, 2009

48. He TC, Sparks AB, Rago C, Hermeking H, Zawel L, da Costa LT, Morin PJ, Vogelstein B and Kinzler KW: Identification of c-MYC as a target of the APC pathway. Science 281: 1509-1512, 1998.

49. Mann B, Gelos M, Siedow A, Hanski ML, Gratchev A, Ilyas M Bodmer WF, Moyer MP, Riecken EO, Buhr HJ and Hanski C: Target genes of beta-catenin-T cell-factor/lymphoid-enhancerfactor signaling in human colorectal carcinomas. Proc Natl Acad Sci USA 96: 1603-1608, 1999.

50. Shtutman M, Zhurinsky J, Simcha I, Albanese C, D'Amico M, Pestell R and Ben-Ze'ev A: The Cyclin D1 gene is a target of the beta-catenin/LEF-1 pathway. Proc Natl Acad Sci USA 96 5522-5527, 1999.

51. Tetsu $\mathrm{O}$ and McCormick F: Beta-catenin regulates expression of Cyclin D1 in colon carcinoma cells. Nature 398: 422-426, 1999 .

52. Kouzarides T: Chromatin modifications and their function. Cell 128: 693-705, 2007.

53. Daujat S, Zeissler U, Waldmann T, Happel N and Schneider R: HP1 binds specifically to Lys26-methylated histone H1.4, whereas simultaneous Ser27 phosphorylation blocks HP1 binding. J Biol Chem 280: 38090-38095, 2005. 
54. Wagner EJ and Carpenter PB: Understanding the language of Lys36 methylation at histone H3. Nat Rev Mol Cell Biol 13: $115-126,2012$.

55. Eilers M and Eisenman RN: Myc's broad reach. Genes Dev 22: 2755-2766, 2008.

56. Eferl R and Wagner EF: AP-1: a double-edged sword in tumorigenesis. Nat Rev Cancer 3: 859-868, 2003.

57. Smith DR, Myint T and Goh HS: Over-expression of the c-myc proto-oncogene in colorectal carcinoma. Br J Cancer 68: 407-413, 1993.

58. Magrisso IJ, Richmond RE, Carter JH, Pross CB, Gilfillen RA and Carter HW: Immunohistochemical detection of RAS, JUN, FOS, and p53 oncoprotein expression in human colorectal adenomas and carcinomas. Lab Invest 69: 674-681, 1993.

59. Nateri AS, Spencer-Dene B and Behrens A: Interaction of phosphorylated c-Jun with TCF4 regulates intestinal cancer development. Nature 437: 281-285, 2005.

60. Gan XQ, Wang JY, Xi Y, Wu ZL, Li YP and Li L: Nuclear Dvl, c-Jun, beta-catenin, and TCF form a complex leading to stabilization of beta-catenin-TCF interaction. J Cell Biol 180: 1087-1100, 2008.

61. Suto R, Tominaga K, Mizuguchi H, Sasaki E, Higuchi K, Kim S, Iwao $\mathrm{H}$ and Arakawa T: Dominant-negative mutant of c-Jun gene transfer: a novel therapeutic strategy for colorectal cancer. Gene Ther 11: 187-193, 2004

62. Bartkova J, Lukas J, Strauss M and Bartek J: The PRAD-1/ Cyclin D1 oncogene product accumulates aberrantly in a subset of colorectal carcinomas. Int J Cancer 58: 568-573, 1994.

63. Hulit J, Wang C, Li Z, Albanese C, Rao M, Di Vizio D Shah S, Byers SW, Mahmood R, Augenlicht LH, Russell R and Pestell RG: Cyclin D1 genetic heterozygosity regulates colonic epithelial cell differentiation and tumor number in ApcMin mice. Mol Cell Biol 24: 7598-7611, 2004.

64. Fu L, Chen L, Yang J, Ye T, Chen Y and Fang J: HIF-1alphainduced histone demethylase JMJD2B contributes to the malignant phenotype of colorectal cancer cells via an epigenetic mechanism. Carcinogenesis 33: 1664-1673, 2012.

65. Luo W, Chang R, Zhong J, Pandey A and Semenza GL: Histone demethylase JMJD2C is a coactivator for hypoxia-inducible factor 1 that is required for breast cancer progression. Proc Natl Acad Sci USA 109: E3367-E3376, 2012.
66. Kim TD, Shin S, Berry WL, Oh S and Janknecht R: The JMJD2A demethylase regulates apoptosis and proliferation in colon cancer cells. J Cell Biochem 113: 1368-1376, 2012.

67. Mallette FA, Mattiroli F, Cui G, Young LC, Hendzel MJ, Mer G, Sixma TK and Richard S: RNF8- and RNF168-dependent degradation of KDM4A/JMJD2A triggers 53BP1 recruitment to DNA damage sites. EMBO J 31: 1865-1878, 2012.

68. Young LC, McDonald DW and Hendzel MJ: Kdm4b histone demethylase is a DNA damage response protein and confers a survival advantage following gamma-irradiation. J Biol Chem 288: 21376-21388, 2013

69. Slee RB, Steiner CM, Herbert BS, Vance GH, Hickey RJ, Schwarz T, Christan S, Radovich M, Schneider BP, Schindelhauer D and Grimes BR: Cancer-associated alteration of pericentromeric heterochromatin may contribute to chromosome instability. Oncogene 31: 3244-3253, 2012.

70. Toyokawa G, Cho HS, Iwai Y, Yoshimatsu M, Takawa M, Hayami S, Maejima K, Shimizu N, Tanaka H, Tsunoda T, Field HI, Kelly JD, Neal DE, Ponder BA, Maehara Y, Nakamura Y and Hamamoto R: The histone demethylase JMJD2B plays an essential role in human carcinogenesis through positive regulation of cyclin-dependent kinase 6. Cancer Prev Res 4: 2051-2061, 2011.

71. Dawson MA, Prinjha RK, Dittmann A, Giotopoulos G, Bantscheff M, Chan WI, Robson SC, Chung CW, Hopf C, Savitski MM, Huthmacher C, Gudgin E, Lugo D, Beinke S, Chapman TD, Roberts EJ, Soden PE, Auger KR, Mirguet O, Doehner K, Delwel R, Burnett AK, Jeffrey P, Drewes G, Lee K, Huntly BJ and Kouzarides T: Inhibition of BET recruitment to chromatin as an effective treatment for MLL-fusion leukaemia. Nature 478: 529-533, 2011.

72. Zuber J, Shi J, Wang E, Rappaport AR, Herrmann H, Sison EA, Magoon D, Qi J, Blatt K, Wunderlich M, Taylor MJ, Johns C, Chicas A, Mulloy JC, Kogan SC, Brown P, Valent P, Bradner JE, Lowe SW and Vakoc CR: RNAi screen identifies Brd4 as a therapeutic target in acute myeloid leukaemia. Nature 478: 524-528, 2011. 